\title{
Characterization of the Educational Innovation Process: Teaching Concerns and Results in the Teaching and Learning Process in a Chilean University Over 5 Years
}

\author{
Alejandra Ruiz-Garrido \\ Universidad del Desarrollo \\ Rocío Vélez-Rivera \\ Universidad del Desarrollo \\ Priscila Leal-Orellana \\ Universidad del Desarrollo \\ Daiana Quintiliano-Scarpelli \\ Universidad del Desarrollo
}

This study arises from the need to identify the concerns of teachers for their pedagogical practice, characterizing this process. 91 articles of educational innovation projects were analyzed, between 2014 and 2018, in which 371 teachers and 9,509 students participated. A matrix was developed with identification data and variables based on the concerns focused on students and teachers, their results and the type of innovation used. The variables were associated using descriptive and bivariate statistics (chisquare and fisher's exact test) using Stata 14.1 software. Among the main results, the concerns towards the students stand out, most frequently of the variable "application of the theory". On the other hand, the main concerns focused on teachers were "curricular planning" and the "use of methodologies". "Peer-to-peer learning with the use of keyboards" and "Flipped Classroom_Learning" were the most frequently implemented innovations, showing interest in active methodologies. The results obtained allow us to reflect on innovation in higher education and decide on empirical data from the experience of teachers.

Keywords: university teaching, educational innovation, teaching concerns

\section{INTRODUCTION}

Reviewing UNESCO's statements regarding that "the rapid changes in contemporary societies call into question what should be taught and how learning takes place" (2013, p. 14), along with those of the OECD (2019) and the World Bank (2019), regarding the quality of higher education, highlights the need to integrate methodological innovations that prepare students for the working world of the 21 st century, a challenge that these institutions must take on. 
In this regard, most of these institutions have declared to work in a student-centered educational project, encouraging their teachers as the main factor for the transformation required to innovate in the teachinglearning process. In the particular case of the Universidad del Desarrollo (UDD), it states in its mission "To promote a teaching innovation outlook for the transformation of teaching and learning processes in the development of new generations" (2018, p. 9). For its materialization, the Center for Teaching Innovation (Center) was created, whose mission is "To support the implementation process of the Educational Project, promoting quality teaching in the different instances and faculties of the UDD" (Universidad del Desarrollo, 2018, p. 50). The Center defined Educational Innovation as a dynamic process of change and significant transformation, which seeks to enhance, improve or ratify the procedures generated in educational contexts and learning and teaching processes, through the generation of ideas, products, methodological, evaluative and/or curricular strategies, along with a solution that involves integrating a novelty in a given context, to turn it into a continuous and sustainable practice over time, with transferable solutions beyond the particular context where they arose. (Sein-Echaluce, Fidalgo \& García-Peñalvo 2014; Christensen, Raynor \& McDonald, 2015; Ramírez \& Valenzuela, 2017; Ramírez, 2019).

In 2007, the Teaching Innovation and Strengthening Projects (TISP) program was created, allowing teachers to improve their work through initiatives aimed at strengthening the quality and development of educational innovation. Throughout the program, various concerns have arisen, implementing different methodologies and pedagogical strategies, both analog and technological. For the continuous improvement of this program, the work done has been reflected upon, as pointed out by the International Society for the Scholarship of Teaching and Learning (ISSOTL, 2019). This organization seeks to promote research and encourage the generation of knowledge that transcends particular contexts and allows giving rise to interdisciplinary conversations to create synergies and pro-mote new lines of research in higher education. In this sense, it was decided to review and analyze the yearbooks prepared to disseminate the implemented educational innovations.

The objective of this study focused on characterizing the origin of the concerns for the implemented educational innovation and associating them to the results found, having as evidence the articles of the yearbooks.

\section{METHOD}

\section{Type of Study}

Descriptive, non-experimental, cross-sectional study.

\section{Participants and Context}

Articles were selected from the yearbooks of the TISP program, which gather UDD teaching innovations from the Santiago and Concepción (Chile) campuses, between 2014 and 2018.

A total of 12 faculties (10 from the humanities and engineering area and 2 from the health area), 22 careers and 1 program (16 from the humanities and engineering area and 6 from the health area) participated. As an exclusion criterion, those articles that corresponded to the development of learning support resources were not considered $(n=30)$.

\section{Study Variables}

The operationalization of the variables in this study are described in Tables 1 and 2. For a better understanding, the teachers' concerns were classified into student-centered and self-centered variables. 
TABLE 1

OPERATIONALIZATION OF THE VARIABLES FOCUSED ON STUDENTS, ACCORDING TO CONCERNS AND RESULTS

\begin{tabular}{|c|c|c|}
\hline Variable/Operationalization & Concern & Result \\
\hline Performance & $\begin{array}{l}\text { Low student performance, high } \\
\text { failure rate in subject(s). }\end{array}$ & $\begin{array}{l}\text { Increase in course grade point } \\
\text { average, decrease in failure rate } \\
\text { for course(s). }\end{array}$ \\
\hline Motivation & $\begin{array}{l}\text { Lack of motivation to learn the } \\
\text { contents of the subject(s). }\end{array}$ & $\begin{array}{l}\text { Students motivated to learn the } \\
\text { contents of the subject(s) and } \\
\text { increase in the percentage of } \\
\text { class attendance. }\end{array}$ \\
\hline Participation & $\begin{array}{l}\text { Low class participation and } \\
\text { collaborative work in the } \\
\text { classroom. }\end{array}$ & $\begin{array}{l}\text { Increased participation in classes } \\
\text { and collaborative work. }\end{array}$ \\
\hline Attention in class & $\begin{array}{l}\text { Need to encourage students' } \\
\text { attention in class. }\end{array}$ & $\begin{array}{l}\text { Dynamic classes, students } \\
\text { receptive to the information } \\
\text { provided and willing to } \\
\text { participate in the proposed } \\
\text { activities. }\end{array}$ \\
\hline Application of Theory & $\begin{array}{l}\text { Students memorize the contents } \\
\text { of the course, making it difficult } \\
\text { for them to apply them. Need to } \\
\text { bring students closer to the } \\
\text { professional practice of their } \\
\text { careers. }\end{array}$ & $\begin{array}{l}\text { Students able to apply } \\
\text { theoretical contents in practical } \\
\text { activities, located in contexts } \\
\text { that they will have to face during } \\
\text { their professional practice. }\end{array}$ \\
\hline Communication & $\begin{array}{l}\text { Need to contribute to the } \\
\text { development of written } \\
\text { communication skills (text } \\
\text { writing) and/or oral } \\
\text { communication skills (content } \\
\text { presentation, teacher/student and } \\
\text { student/student interaction). }\end{array}$ & $\begin{array}{l}\text { Improve the quality of texts } \\
\text { elaborated by students and/or } \\
\text { oral presentation of contents. } \\
\text { Development of student/teacher, } \\
\text { peer and patient/user } \\
\text { communication skills in } \\
\text { simulated scenarios. }\end{array}$ \\
\hline Digital Knowledge & $\begin{array}{l}\text { Need to incorporate } \\
\text { technological resources that } \\
\text { favor learning. Lack of } \\
\text { knowledge in the use of the } \\
\text { institutional platform tools } \\
\text { (Moodle). }\end{array}$ & $\begin{array}{l}\text { Development of technological } \\
\text { skills by learning to use } \\
\text { resources available at the } \\
\text { university and on the web, which } \\
\text { contributed to the teaching- } \\
\text { learning process. Increased use } \\
\text { of the institutional platform, } \\
\text { favoring interaction and timely } \\
\text { feedback. }\end{array}$ \\
\hline Specific career competencies & $\begin{array}{l}\text { Need to develop specific } \\
\text { competencies stated in the } \\
\text { educational model of the degree } \\
\text { program. }\end{array}$ & $\begin{array}{l}\text { Development of the specific } \\
\text { competency(ies) declared as a } \\
\text { concern and that gave rise to the } \\
\text { innovation. }\end{array}$ \\
\hline Others & $\begin{array}{l}\text { Other needs or concerns that do } \\
\text { not match the variables listed in } \\
\text { the first rows of the table. }\end{array}$ & $\begin{array}{l}\text { The implementation of the } \\
\text { innovation contributed to } \\
\text { solving the problem initially } \\
\text { raised. }\end{array}$ \\
\hline
\end{tabular}




\section{TABLE 2 \\ OPERATIONALIZATION OF THE VARIABLES FOCUSED ON TEACHERS, ACCORDING TO THEIR CONCERNS AND RESULTS}

\begin{tabular}{|c|c|c|}
\hline Variable/Operationalization & Concern & Result \\
\hline Use of methodologies & $\begin{array}{l}\text { Need to use active teaching } \\
\text { strategies that promote learning } \\
\text { and timely feedback. }\end{array}$ & $\begin{array}{l}\text { Teacher(s) trained in an active } \\
\text { and innovative teaching } \\
\text { strategy that favored learning } \\
\text { and timely feedback. }\end{array}$ \\
\hline Digital Knowledge & $\begin{array}{l}\text { Need to incorporate } \\
\text { technological resources that } \\
\text { favor learning. Lack of } \\
\text { knowledge in the use of the } \\
\text { institutional platform tools } \\
\text { (Moodle). }\end{array}$ & $\begin{array}{l}\text { Teachers with skills in the use } \\
\text { of technological resources } \\
\text { available at the university and } \\
\text { on the web, which contributed } \\
\text { to the teaching-learning } \\
\text { process. Greater use of the } \\
\text { institutional platform, using it } \\
\text { as a virtual classroom for the } \\
\text { subject. }\end{array}$ \\
\hline Classroom time optimization & $\begin{array}{l}\text { Due to the dynamics and } \\
\text { structure of the class, it is } \\
\text { difficult to carry out feedback } \\
\text { and practical activities. }\end{array}$ & $\begin{array}{l}\text { The innovation implemented } \\
\text { made it possible to optimize } \\
\text { classroom time, favoring } \\
\text { practical activities and feedback } \\
\text { on student learning. }\end{array}$ \\
\hline Curriculum planning & $\begin{array}{l}\text { The course contemplates a high } \\
\text { volume of contents to be } \\
\text { addressed versus the time } \\
\text { dedicated to face-to-face } \\
\text { classes. Need to articulate with } \\
\text { teachers of subjects of the same } \\
\text { line or cycle, approaching } \\
\text { certain contents and evaluation } \\
\text { instances. }\end{array}$ & $\begin{array}{l}\text { The innovation implemented } \\
\text { contributed to the organization } \\
\text { and presentation of the } \\
\text { contents, favoring the teaching- } \\
\text { learning process. Opportunities } \\
\text { for reflection and articulation } \\
\text { among teachers were generated. }\end{array}$ \\
\hline Evaluation & $\begin{array}{l}\text { Need to optimize the learning } \\
\text { evaluation process. }\end{array}$ & $\begin{array}{l}\text { Optimal evaluation and } \\
\text { feedback process according to } \\
\text { the needs of the subject, with } \\
\text { instruments validated by } \\
\text { teachers and students. }\end{array}$ \\
\hline Others & $\begin{array}{l}\text { Other needs or concerns that do } \\
\text { not match the variables listed in } \\
\text { the first rows of the table. }\end{array}$ & $\begin{array}{l}\text { How much the implementation } \\
\text { of the innovation contributed to } \\
\text { solving the problem initially } \\
\text { raised. }\end{array}$ \\
\hline
\end{tabular}

\section{Instruments and Procedures}

For the systematization of the information, a matrix was prepared with identification data for each article, considering: year, faculty, career, location, number and gender of teachers and number of students who participated.

In addition, categorical variables (Tables 1 and 2) were classified based on the concerns focused on students and teachers, which were recorded according to the presence or absence of the attribute. These emerged from the re-searchers' calibration process when analyzing the documents, as well as from their empirical work as coordinators of teaching innovation projects. 
Finally, the results and difficulties faced in each project were identified, as well as the type of innovation pro-posed as a means to solve the difficulties identified, the evaluation instruments and their respective assessment.

\section{Data Analysis}

In this study, teaching concerns, their respective results and the type of innovation implemented were analyzed. The variables studied are mostly of a dichotomous nominal qualitative nature and the descriptive statistics were presented by means of absolute and relative frequencies. The association was determined by means of the Chi-square test or Fisher's Exact test (when more than $20 \%$ of the cells presented $n<5$ ). A pvalue $<0.05$ was considered significant, using Stata 14.1 software.

\section{RESULTS}

91 projects were analyzed, with the participation of 9,509 students and 371 teachers, $65 \%$ female and $35 \%$ male.

The disciplinary area that carried out the most educational innovation projects was health, including the faculties of Health Sciences (23\%) and Medicina Clínica Alemana-Universidad del Desarrollo (19\%). This was followed by the humanities area with $9 \%$ of the total number of projects, specifically the Faculty of Communications. The career with the greatest presence in the program was Nursing (12\%), followed by Nutrition and Dietetics (9\%) and Phonoaudiology (8\%).

\section{Identification of Educational Innovations}

The years with the highest implementation of innovation projects were 2014 and 2017, which accounted for $48 \%$ of the total. On the other hand, the one with the lowest frequency was 2018 , reaching $15 \%$. Among the most used educational innovations, "Peer learning with the use of keyboards" (18.7\%), "Flipped Classroom_Learning" and "Disciplinary innovations" stand out from the total number of projects, with $12.1 \%$ respectively. The rest of the innovations, corresponding to "other innovations", with $44 \%$ of the total number of projects, represent proposals of different types, with and without the use of technology, used in 4 or fewer projects.

\section{TABLE 3}

\section{DISTRIBUTION OF TYPE OF INNOVATION BY YEAR}

\begin{tabular}{|c|c|c|c|c|c|c|}
\hline \multirow[t]{3}{*}{ Type of Innovation } & \multicolumn{6}{|c|}{ Year } \\
\hline & 2014 & 2015 & 2016 & 2017 & 2018 & Total \\
\hline & $\%(n)$ & $\%(n)$ & $\%(n)$ & $\%(n)$ & $\%(n)$ & $\%(n)$ \\
\hline $\begin{array}{l}\text { Peer-to-peer learning with } \\
\text { the use of keypads }\end{array}$ & $7,7(7)$ & $3,3(3)$ & $3,3(3)$ & $3,3(3)$ & $1,1(1)$ & $18,7(17)$ \\
\hline Flipped & $0(0)$ & $1,1(1)$ & $1,1(1)$ & $5,5(5)$ & $4,4(4)$ & $12,1(11)$ \\
\hline Classroom_Learning & & & & & & \\
\hline Disciplinary Innovations & $1,1(1)$ & $1,1(1)$ & $0(0)$ & $5,5(5)$ & $4,4(4)$ & $12,1(11)$ \\
\hline Evaluation methods & $3,3(3)$ & $0(0)$ & $1,1(1)$ & $1,1(1)$ & $2,2(2)$ & $7,6(7)$ \\
\hline Project-based learning & $2,2(2)$ & $3,3(3)$ & $0(0)$ & $0(0)$ & $0(0)$ & $5,5(5)$ \\
\hline Other innovations & $10(9)$ & $11(10)$ & $11(10)$ & $8,8(8)$ & $3,3(3)$ & $44,0(40)$ \\
\hline
\end{tabular}

\section{Concerns for Educational Innovation}

The identification of concerns made it possible to determine that $68 \%$ are focused on students and $32 \%$ on teachers. In addition, only $17.6 \%$ of the projects had one concern for carrying out the innovation, while $82.4 \%$ expressed more than one concern. 
Of the concerns related to students, "application of theory" was the main one (34\%). In second place was "career-specific competence" (32\%). In third place, "participation" (26\%). The concern least present in the projects was "digital knowledge", considered in 5 projects $(5 \%)$.

\section{FIGURE 1 \\ FREQUENCY OF STUDENT-FOCUSED CONCERNS}

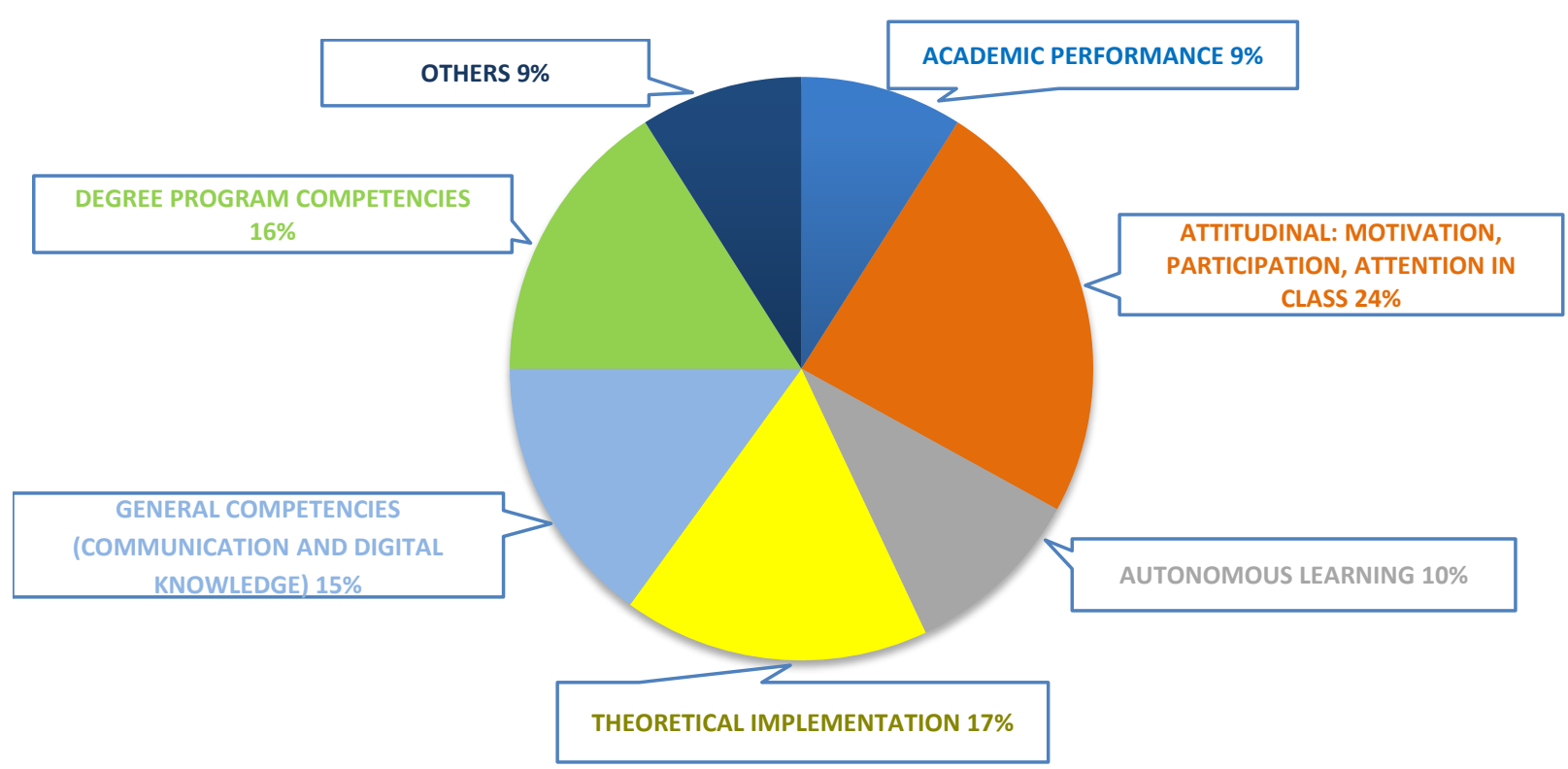

The same analysis was made for the concerns focused on teachers. In this regard, it can be noted that the one related to the "use of methodologies" is present in $29 \%$ of the projects, followed by "curricular planning" present in $24 \%$. Finally, "digital knowledge" is present in $16 \%$ of the projects.

FIGURE 2

FREQUENCY OF CONCERNS FOCUSED ON THE TEACHER

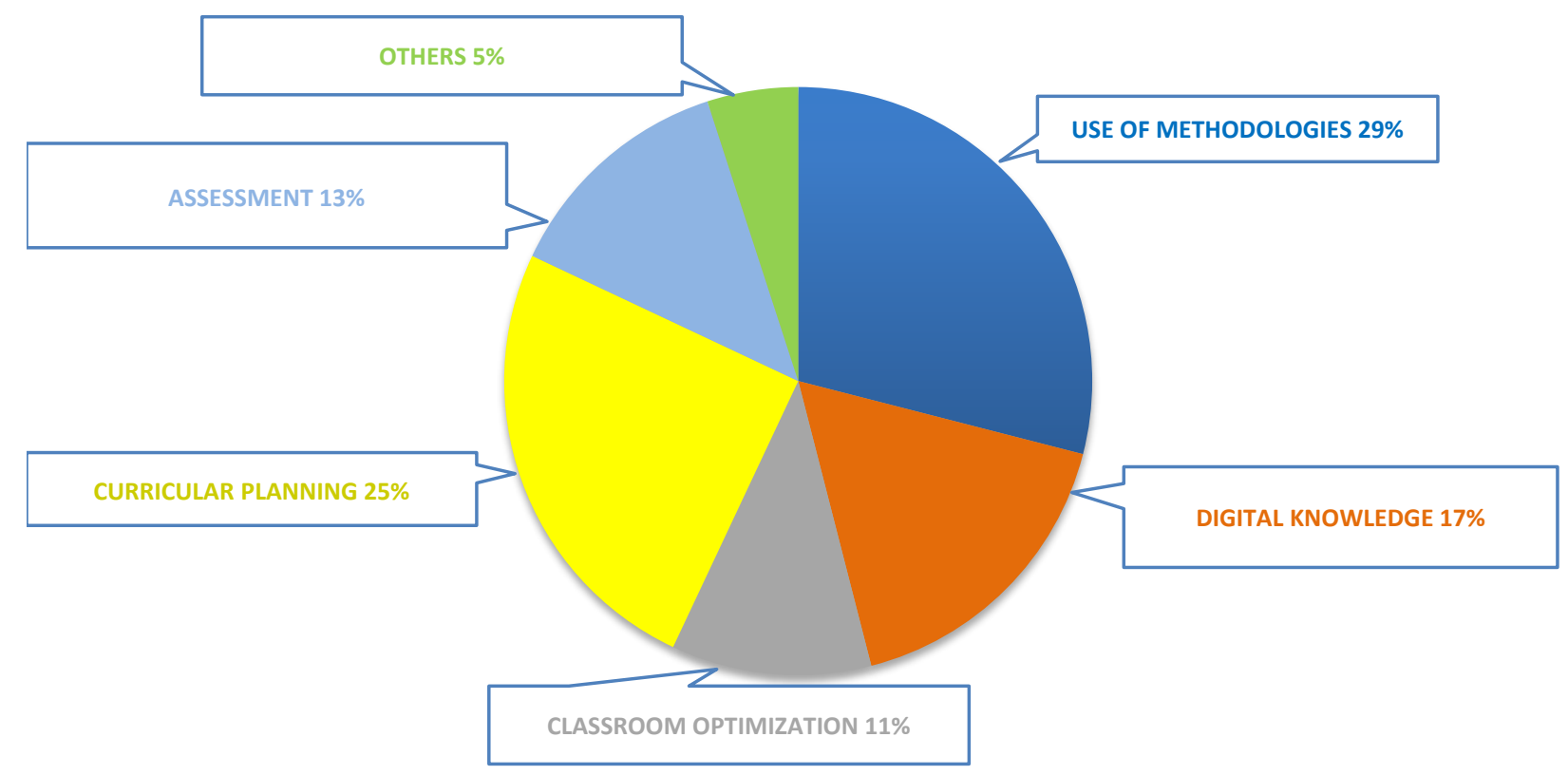

80 Journal of Higher Education Theory and Practice Vol. 21(15) 2021 


\section{Association of Concerns and Results Achieved by Projects}

Below is the association between the concerns focused on the students for educational innovation and the results achieved according to the teacher description.

When teachers sought to work on the concern "motivation" of their students, they achieved significant results in aspects such as "participation" (13.2\%), "attention in class" (4.4\%), "autonomous learning" $(6.6 \%)$ and "application of theory" (6.6\%). However, no significant association was found with results with respect to "motivation".

When teachers focused on the concern "autonomous learning", they achieved significant associations with results in "participation" (17.6\%), "application of theory" (11\%) and "autonomous learning" (11\%).

When the concerns of "academic performance" (14.3\%), "motivation" $(13.2 \%)$, "participation" (22\%), "autonomous learning" (18\%) and "career-specific competencies" (23.1\%) were addressed, they had a significant impact on the "participation" result.

The same analysis was then carried out with respect to the concerns focused on teachers and their association with the results present in the projects. 


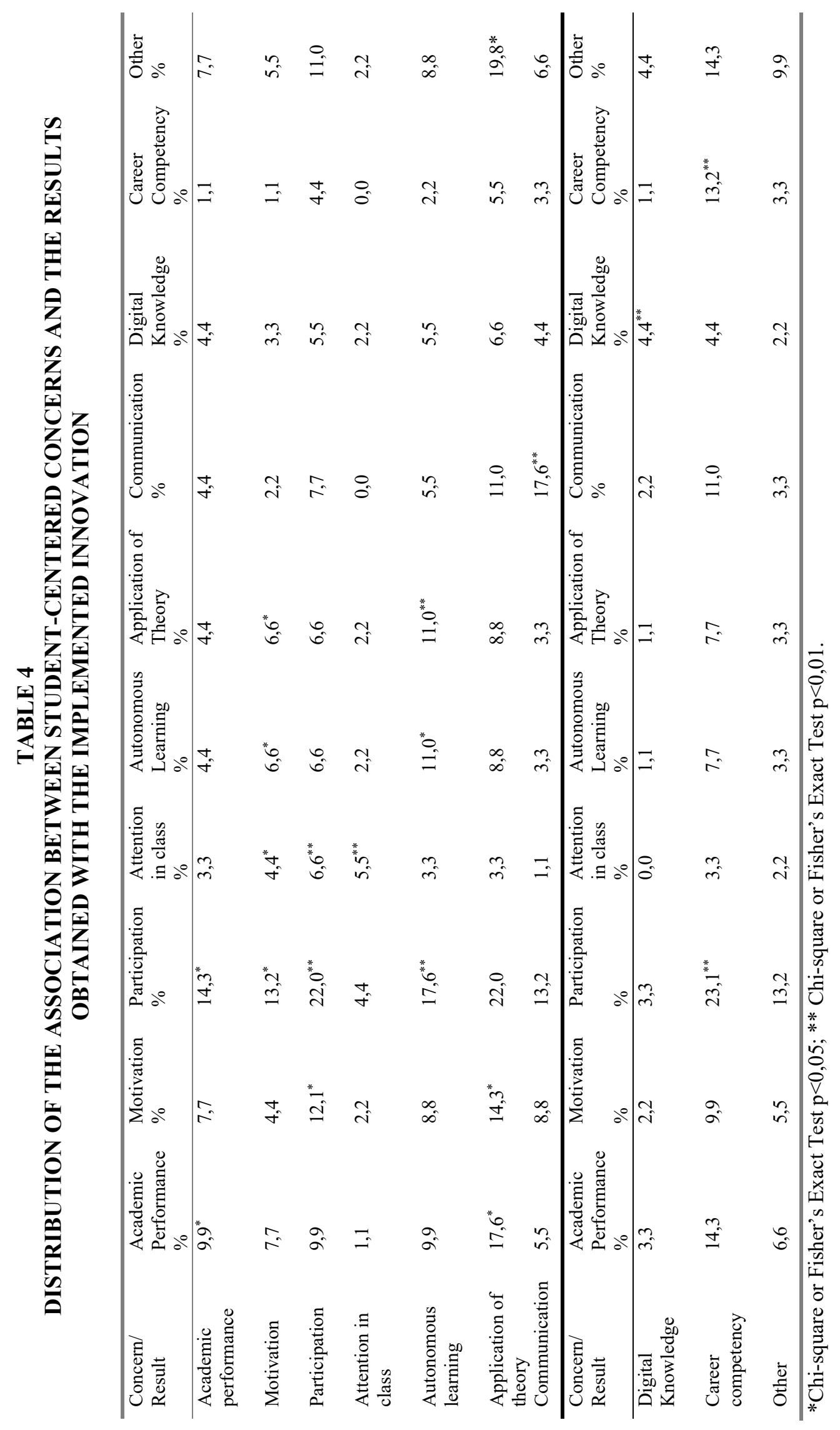

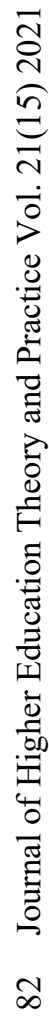


TABLE 5

DISTRIBUTION OF THE ASSOCIATION BETWEEN THE CONCERNS FOCUSED ON TEACHERS AND THE RESULTS OBTAINED WITH THE IMPLEMENTED INNOVATION

\begin{tabular}{|c|c|c|c|c|c|c|}
\hline Concern/Result & $\begin{array}{c}\text { Methodology } \\
\%\end{array}$ & $\begin{array}{c}\text { Digital } \\
\text { Knowledge } \\
\%\end{array}$ & $\begin{array}{c}\text { Classroom } \\
\text { Time } \\
\%\end{array}$ & $\begin{array}{c}\text { Curricular } \\
\text { Plan } \\
\%\end{array}$ & $\begin{array}{c}\text { Evaluation } \\
\% \\
\%\end{array}$ & $\begin{array}{c}\text { Others } \\
\% \\
\%\end{array}$ \\
\hline Methodology & $13,2^{* *}$ & 2,2 & 2,2 & 4,4 & 0,0 & 4,4 \\
\hline $\begin{array}{l}\text { Digital } \\
\text { Knowledge }\end{array}$ & 2,3 & $3,3^{* *}$ & 0,0 & 0,0 & 0,0 & 2,2 \\
\hline $\begin{array}{l}\text { Classroom } \\
\text { Time }\end{array}$ & 1,1 & 0,0 & $3,3^{*}$ & 2,2 & 0,0 & $5,5^{* *}$ \\
\hline Curricular Plan & 5,5 & 1,1 & 2,2 & $7,7^{* *}$ & 0,0 & 3,3 \\
\hline Evaluation & 2,2 & 0,0 & 1,1 & 2,2 & $2,2^{*}$ & 2,2 \\
\hline Others & 0,0 & 0,0 & $2,2^{*}$ & 1,1 & 0,0 & 2,2 \\
\hline
\end{tabular}

*Chi-square or Fisher's Exact Test $\mathrm{p}<0,05$; ** Chi-square or Fisher's Exact Test $\mathrm{p}<0,01$.

Concerns related to teachers mostly presented significant associations with their related outcomes (e.g., evaluation with evaluation), only the concern "time in the classroom" presented significant associations with "other" out-comes.

\section{DISCUSSION}

Considering the information by faculty and career, the high participation of the health area stands out. This could reflect an organizational view, as a faculty, to promote change in the teaching-learning process, in addition to the particular interest or willingness of teachers-professionals of this discipline to innovation. This is related to what Castillo et al. (2014) stated when they pointed out that curricular and teaching changes are opportunities to provide the student with a more efficient learning system.

Understanding that the nature of this discipline requires constant updating of knowledge, a study by Matus et al. (2017) highlights the importance of training in education for professionals in this area to understand the educational process and its quality, as well as to incorporate teaching-learning strategies in the classroom that bring students closer to their professional practice, given the difficulties in accessing clinical fields.

Secondly, and from what has been observed with respect to students, there is a greater number of significant as-sociations related to attitudinal aspects than to academic performance, such as, for example, encouraging class participation, autonomy and motivation. These attitudes are fundamental for the development of autonomous, independent and self-regulated work, proposed by constructivism as a learning model for students to become managers committed to their learning, as pointed out by León, Risco \& Alarcón (2014).

In contrast, the significant associations linked to teachers are related to the achievement of pedagogical competencies and better professional performance. This can be linked to the fact that most teachers do not have pedagogical studies, which accentuates the need to strengthen their pedagogical practice (González, Rodríguez, García \& Narváez, 2016).

Thirdly, it highlights the scope of addressing "motivation", by achieving greater participation, attention in clas-ses, autonomous and procedural learning, fostering strategies for the development of self-regulated learning, such as self-motivation as a tool for lifelong learning (Navea-Martín \& Suárez-Riveiro, 2017). This is supported in the idea presented by Ardisana (2013) when considering that motivation should be worked on throughout the class and not perform actions detrimental to the development of the didactic action. 
On the other hand, having results in "participation" when working on various concerns, invites us to think that the mere fact of implementing an innovation and modifying the class, favors the participation of students making them the architects of their learning and inviting them to develop communicative competencies necessary for their professional life (Moliní \& Sánchez-González, 2019).

Finally, it is important to highlight the difference detected between the concerns addressed in the projects, since these were mainly focused on weaknesses or problems in the students. This raises the need to generate greater in-stances of reflection regarding the role played as teachers in order to broaden the focus that originates an educational innovation. As Cañedo \& Figueroa (2013) point out, teaching practice refers to different dimensions that can be connected during the teaching-learning process.

\section{CONCLUSIONS}

Inquiring about the educational innovations that we have carried out as a university in the last five years has led us to reflect on our role as a Center, with the purpose of optimizing the process of accompanying teachers in the innovation process.

According to the results obtained, it is noteworthy that the hypothesis referring to the existence of a direct relationship between the concern identified and the result obtained was not fulfilled, since the results did not always state their relationship with the innovation's origin. This type of finding raises the questions: whether the selection of the type of innovation is adequate to address the identified concern or whether the teachers declare all the results obtained with the innovation implemented. In this regard, it is important to guide teachers in the formulation of their innovation projects, so that the concern to be addressed is aligned with the innovation to be implemented and the expected results. In addition, it is crucial to systematize and evaluate the experience obtained, in order to declare all the results obtained and opportunities for improvement.

Regarding the projection of this research, in addition to continue systematizing the new projects, it is expected to investigate the information gathered in the matrix regarding the difficulties faced in the innovation process, the evaluation instruments and their respective assessment given to the projects in future analyses. In addition to continue systematizing in the matrix the projects of 2019 in order to continue researching the innovation process in higher education.

The knowledge obtained in this study has not only been useful for our Center and University, but we also believe that it may be of interest to other institutions of higher education, also inquiring about the main concerns that lead a teacher to innovate in their pedagogical practice and the results obtained. Therefore, the information obtained in this research not only allows us to have an appreciation of the innovation process that arises from the teacher, but also allows institutions to generate actions that encourage teachers to innovate and actions aimed at supporting them in this process.

\section{ACKNOWLEDGEMENT}

Translated \& edited by American Publishing Services (https://americanpublishingservices.com/).

\section{REFERENCES}

Ardisana, E.F.H. (2013). La motivación como sustento indispensable del aprendizaje en los estudiantes universitarios. Pedagogía Universitaria, 17(4). Retrieved from http://cvi.mes.edu.cu/peduniv/index.php/peduniv/article/view/39/0

Banco Mundial. (2019). Informe sobre el Desarrollo Mundial 2019: La naturaleza cambiante del trabajo, cuadernillo del "Panorama general. Banco Mundial, Washington, DC. Licencia: Creative Commons de Reconocimiento CC BY 3.0 IGO. Retrieved from http://documents.worldbank.org/curated/en/767331554985479543/pdf/Main-Report.pdf

Cañedo Ortiz, T.D.J., \& Figueroa Rubalcava, A.E. (2013). La práctica docente en educación superior: Una mirada hacia su complejidad. Sinéctica, (41), 2-18. Retrieved from 
http://www.scielo.org.mx/scielo.php?script=sci_arttext\&pid=S1665-

109X2013000200004\&lng=es\&tlng $=$ es

Castillo, M., Hawes, G., Castillo, S., Romero, L., Rojas, A. M., Espinoza, M., \& Oyarzo, S. (2014). Cambio educativo en las Facultades de Medicina. Revista Médica de Chile, 142(8), 1056-1060. https://dx.doi.org/10.4067/S0034-98872014000800013

Christensen, C.M., Raynor, M.E., \& McDonald, R. (2015). What is disruptive innovation. Harvard Business Review, 93(12), 44-53. Retrieved from http://pedrotrillo.com/wpcontent/uploads/2016/01/Whatisdisruptiveinnovation.pdf

González, M.L.N., Rodríguez, M.A.G., García, L.J.M., \& Narváez, C.J.A. (2016). La Importancia de la Pedagogía del Docente Universitario en la Unidad Académica de Contaduría y Administración de la Universidad Autónoma de Nayarit. Educateconciencia, 8(9). Retrieved from http://tecnocientifica.com.mx/educateconciencia/index.php/revistaeducate/article/view/23

ISSOTL. (2019). International Society for the Scholarship of Teaching and Learning Homepage. Retrieved August 22, 2019, from https://www.issotl.com/

León Urquijo, A.P., Risco del Valle, E., \& Alarcón Salvo, C. (2014). Estrategias de aprendizaje en educación superior en un modelo curricular por competencias. Revista de la Educación Superior, 43(172), 123-144. Retrieved from http://www.scielo.org.mx/scielo.php?pid=S0185$27602014000400007 \&$ script $=$ sci_abstract\&tlng=en

Matus, B., Ortega, B., Parra, P., Ortiz, M., Márquez, U., Stotz, R., \& Fasce, H. (2017). Condiciones del contexto educativo para ejercer el rol docente en Ciencias de la Salud. Un enfoque cualitativo. Revista Médica de Chile, 145(7), 926-933. Retrieved from https://scielo.conicyt.cl/pdf/rmc/v145n7/0034-9887-rmc-145-07-0926.pdf

Moliní Fernández, F., \& Sánchez-González, D. (2019). Fomentar la participación en clase de los estudiantes universitarios y evaluarla. REDU. Revista de Docencia Universitaria, 17(1), $211-$ 227. Retrieved from https://riunet.upv.es/handle/10251/123096

Navea-Martín, A., \& Suárez-Riveiro, J. M. (2017). Estudio sobre la utilización de estrategias de automotivación en estudiantes universita-rios. Psicología Educativa, 23(2), 115-121. Retrieved from https://reader.elsevier.com/reader/sd/pii/S1135755X17300192?token= 3BE5646C362C96E4A01862EF54262BBA789B74081F2FF56D3DC69C3DA5F615945CF7E7 BD29C4FEEC03ADB24BB2396B1F

OECD. (2019). Trends Shaping Education 2019. OECD Publishing, París. https://doi.org/10.1787/trends_edu-2019-en

Ramírez Montoya, M.S. (2019, March). Docencia universitaria: De la innovación a la investigación. Comunicación presentada en el III Seminario de Innovación Docente, IDEA. Santiago de Chile: Universidad del Desarrollo. Retrieved from https://idea.udd.cl/\#!/seminario-idea

Ramírez Montoya, M.S., \& Valenzuela González, J.R. (Eds.). (2017). Innovación educativa. Investigación, formación, vinculación y visibilidad. España: Editorial Síntesis.

Sein-Echaluce, M.L., Fidalgo Blanco, Á., \& García-Peñalvo, F.J. (2014). Buenas prácticas de Innovación Educativa: Artículos selecciona-dos del II Congreso Internacional sobre Aprendizaje, Innovación y Competitividad, CINAIC 2013. Revista de Educación a Distancia, (44). Retrieved from https://revistas.um.es/red/article/view/254011

UNESCO. (2013). Enfoques estratégicos sobre las TICS en educación en América Latina y el Caribe. OREAL/ UNESCO: Santiago, Chile. Retrieved from http://www.unesco.org/new/fileadmin/MULTIMEDIA/FIELD/Santiago/images/ticsesp.pdf

Universidad del Desarrollo. (2018). UDD Futuro, Proyecto Educativo. Retrieved from https://uddfuturo.udd.cl/files/2018/07/Proyecto-Educativo-UDD-FUTURO.pdf 